\title{
Khushal Khan Khattak Philosophy of Education
}

\author{
* Dr. Niaz Muhammad Aajiz, Associate Professor (Corresponding Author) \\ ** Dr. Khisro Kalim Raza, Head \\ *** Ghazala Naheed Baig, Lecturer
}

\begin{abstract}
Khushal Khan Khattak believed that the meaning of education is hidden in the training of individuals. He considers this training important for him from childhood to his death. Moreover, he feels free from the boundary walls of a school or college. In other words, he is a champion of informal education. For this purpose, he considers the entire earth as a school and all the things of the universe are teachers. In this regard Khushal's ultimate reliance is upon the character building, Development of ego/self-respect, personality development, and inclusion of Moral values, leadership training, and acquiring different skills, required for complete living. Khushal Khan Khattak's this belief and perception of education is very much in line with the educational definitions of different eminent educations and educational objectives. This is the reason that besides his other celebrated titles he got the unique title of an educationist as well.

Keywords: Educationist, Character Building, Personality Development, Moral Values, Skills Introduction

Khushal Khan Khattak was a legend a great poet of Pashto. Most of the great thinkers of the world were poets. It is also a strange fact that literature of the world started from the poetry. Khushal Khan Khattak was one of them who contributed a wonderful contribution to Pashto literature as well as to the global literature. His educational thoughts were appreciated by well-known and renowned persons. The Great Khushal, came into the picture by Maj. Raverty in his selection of Afghan Poetryll in 1862 and works of Bidlof and Powdin. Allama Iqbal write his essay on Khushal with the help of Raverty's selection in 1927 at Hyderabad, as Khushal Khan Khattak, Afghan poet and worrior, which was published in a magazine named, Sub Ras .which boost his introduction in the subcontinent. The books which were written by Khushal Khan were not available in the market, though in 1869, H.W.Belew has printed, Dewan-e- Khushall from Peshawar and the selection of khushal's poetry by Dewan Karak Singh from Peshawar.

Allama Muhammad Iqbal is the National poet of Pakistan, whereas Khushal Khan Khattak is a great Pashtun poet. Both were the genius of their Muslim and Afghan society. No doubt that a distance of three century lying between them, but circumstances of their period indicates that their vision was so high that they read the horizon very clearly and awoke the nation by describing to them, their glorious old history, traditions, faith and philosophy, present political, social and economic condition, and the coming brighter future by their, provoking poetry and writings. The Great Khushal Khan was alive in the period of the Mughal empire of Shah Jahan and Aurangzeb Alamgir and served their kingdom to the entire capacity and capability, but at a point, he became the enemy of Aurangzeb, as he has put him in prison for five years to safeguard his kingdom from the popularity of Khushal Khan, because he was not only the man of word and wisdom but also a warrior in the battlefield and fought for Mughal empire for their dynasty. Khushal Khan Khattak rightly claims that: Pashto is highly indebted to me, whether its prose, poetry, or script. (At first) having no script, there was no book in it; it is me that authored several books in it. (Qabil, 2006). It indicates his scholarship. Surely by practicing his teachings, the achievement of objectives will become easy and life will become joyous for individuals. His fame around the world is only due to his scholarship. Khushal Khan Khattak was aware of it and expressed it in these words:
\end{abstract}

\footnotetext{
* Islamia College University Peshawar Email: niaz@icp.edu.pk

** Department of Education, SUIT, Peshawar

*** Department of Education, Abdul Wali Khan University Mardan Email: ghazaldir786@gmail.com
} 
"My fame has been spread in three things, generosity, learning and writing

"In three things - generosity, learning and writing has my fame spread"

In another place Begum and Khadija, (2007) quoted him thus:

"I love book, bow and pen for everything else, in fatigue, pain and suffering"

If I were not trapped in hunting, I would be able to attain all the rest of worldly knowledge"

He was extremely very keen in this regard and his style was greatly educational. He intended to educate his individuals and transfer maximum knowledge to them. (Daud, 2007).

"This is a tradition of the world that individuals seek knowledge from each other

No one can become a teacher till that he becomes a learner"

No doubt that behavior of the society is based on education; it can make society happier. The crucial and extremely significant is the necessity of social education for attaining an improved and better-off community (Naseem, 2007). Khushal Khan says in his famous book Dastar Nama that education has no borders, parents have to ceaselessly struggle for their offspring from their infancy to their adulthood." Prof. Arif. (2007) argued that his Dastar Nama has 20 skills and 20 qualities which is a masterpiece of work of his educational thoughts. It deals with the art of leadership which has the vital essentials, modesty, integrities, talents, and abilities for a ruler. He took the start of the book with a masterpiece couplet that:

"Those who tie the turban are in thousands

But those who qualify for it are few"

He feels fear from an ignorant person: "I do not have such fear of the leopard and tiger, as I am frightened from an ignorant" (Armaghan-e-Khushal, 2001)

Mir (1982), in his famous book Khushal and Iqbal, quoted him that he was a protuberant intelligent person. He was aware that a deprived of education a person does not only remain in darkness from his religion but his self as well. Education plays a significant role in the development of his self. As he says:

"Education and wisdom are necessary for a complete religion

\section{Objectives of the Study}

These are not given for looting others"

1. To know about the educational philosophy of Khushal Khan Khattak.

2. To examine his poetry for the teaching-learning process.

3. To explore the views of Khushal Khan about education and progress.

\section{Education Aims at Skills Development}

Mir (1982), Pointed out that Khushal Khan Khattak gives great importance to skills which is the aim of education. The individual that possesses knowledge and skills is the ideal individual. To him skill is very necessary for their individuality as he says in the following couplet:

"When an eagle flies away from your hands, you search it in mountains and deserts to find it. The skill is also a rebel eagle. Do not be in low-spirit in its seeking" And

About the skill, he further says:

Your skill-less son is not your son, do not call him a son

It does not matter if he is strong and wealthy; he is alike of a donkey

Khushal Baba further says:

And skills are good then all these things"

Be skillful and acquire the stars of magnitude

If you are unable to do so you are feeble" (Rasool, 2001).

Rasool, (2001), further stated that Khushal Khan said about an educated person. "A wise person stays away from others because of his knowledge and skill" Education is an aim of education and khushal Khan gives great value to its which is clear from the above-mentioned examples. A poet who became a warrior to resist King Aurangzeb's rule, Khattak was able to defeat the Mughal troops on many occasions. He is considered the father of Pakhtun nationalism and is revered across Pakistan and Afghanistan equally for his efforts to bring unity within feuding Pakhtun tribes. He also wrote in Persian, as was customary for most poets in the wider region of Central and South Asia then. But his main work is in Pashto (Khalique, 2016)

\section{Setting High Targets and Achieving}

Baba advises the people to produce the abilities of eagle not of predators in yourselves, as he says: 


\section{Eagles never struggle for eating the dead \\ Crow and vulture do this job \\ Vultures keep eyes on the tail of tiny bird (chati) \\ While falcon keeps an eye on the crown of peacock}

Khushal says forcefully that powerful people should have a shelter for the weak and helpless. That is a peaceful full society in which weak people are cared for. "The eagle that attacks sparrows, behaves like a vulture". He further teaches that how one can become strong and tied like a pellet-bow. A tied pellet-bow hits the mark properly; the same one can achieve the goal successfully:

A tied pellet bow hits the mark properly

But the loose pellet-bow misses its mark (Rasool, 2001).

According to Shinwari (2020), Khushal Khan Khattak had been a perpetual fountain of inspiration for readers, critics, intellectuals, and scholars because of his multifaceted personality and his immense contribution to Pashto and Pakhtun nation at large.

\section{Education aims to produce leaders and train them}

Begum and Khadija (2007), stated that Khushal Khan advised the leader of his time:

Headship is not everyone's job. Only those can do this, who is ready to pastel their lives and material. A head must be thoughtless of profit or loss and honor must be his only aim" Biddulph (1983). Said that Khushal valued even the company of educated people: "if you are accompanying of wise people...Congratulation to you, your perfect religion with worldly gain" To him, an educated person is aware of the skill of how to talk and how to deal with the people. The incompetent people are not aware of the talking skill...Their talking is sweetest than sweets. The writing of a wise man is and useful than the thousands of meaningless talks" Rasool, (1999), exhorted that in Khushal view if someone is deprived of education, he must set with scholars to become gold:

If a person is stone or clod of desert

They will become gold with the company intellectuals

Further says about an uneducated king:

"An uneducated king and without wisdom when he is crowned is like a wolf or a bull"

\section{Education and Contentment as an Aim}

Syed, (1979), says that Khushal khan considered that contentment is a quality of an educated person; honor will be his top priority. Few coins or otherworldly gains will not make him disgraced.

And what can free man's heart from care?

To bear his contentedly

If the wealth of the world is good

Then dignity is $r$ better than wealth

Make contentment as food for your avaricious eyes

So that heaps of blessings are at your home" (Biddulph, 1983)

A.M. (1982), says that Once Khushal Khan Khattak was distributing some coins in poor people, when the coins finished, his son told father O' Baba! It blackens our fingers. At this Khushal Khan Khattak said: O' my son! Who deliver the coins it blackens their fingers, while those who assemble it and do not spend, it blackens their hearts" If you have the treasure of Qaroon- Be Generous and Distribute it among the poor in the way of Allah,

\section{Building morals of individuals is an aim of Education}

Rasool, (2001), says that khushal wants to develop the morals of people, his teachings stress time and again and emphasize individuals to build their morality and behave others politely, help others if you see them in trouble, have nice and soft talk to them avoid harsh language. Saying: I investigated the morals of man, some men are angles, some are satans, some well-mannered human being and no doubt some are wolves" Speak gently with people and You will be able to win the hearts of other people. Further said: "Do not use harsh language, and do not listen and do not look too bad things...If you do this, congratulation, you are virtuous. Purdil, (year nil), said that Khushal Khan Khattak identified the qualities of good men in these words: "Good Men do not look at the bad deeds of others...If someone treats badly, in response they treat nicely"

\section{Know Thy-Self as Educational Aim}

Kamil, (1951) says that khushal khan's approach and thoughts were like a mystic because he was an Islamic scholar and a practicing Man. According to him at first a person should know himself and then recognition of Allah will be easy for him: 


\author{
"Each hair that is seen the body \\ If one sees it keenly, the gat of recognizing Allah will be open to him \\ $\mathrm{O}$, Khushal! That person is special to Allah \\ Who is bestowed with know- thy self'? \\ Consider that person especial to God,
}

He says about himself and aims to express the status of human being in this world. "I am astonished that what is my importance and finally what will become of me From where I have come and where will I go" Further stated: "World is like a vessel and mine example is like an ant... I swim $\&$ splash in it astonishingly" (Shakeel, 2006).

Khushal says about know-thyself in Dastar Nama: "Those who recognized themselves recognized their Lord" Maghmoom (2005). further said: "If you knew thy-self you knew thy-Lord" If you didn't know thyself, you are unable to know your Lord" (Naseem., 2007).

\title{
Know Thy-Lord as Aim of Education
}

Ghani (2002), documented that Khushal Khan studied himself and creation and then recognized the Allah: 'O' mindless man! Worlds are so many, but you cannot see them... O' the great man all are housed in your heart...O' my dear! Clean the mirror of your heart, if you saw these words, you are closer to Allah". Rasool, (1999), says that Khushal Khan invite the individuals to look around the creation of Allah almighty when you move around the world and think about its creator also if it fascinated you.

"Come on and look at the world with exposed eyes

And see toward the sky which is made beautiful with stars

[The same] see different scenes in the plot of your body

[Then] have a trip to the Gardner at whom every flower is looking"

An Educated person will always be bowed to Allah. He will be thankful to his lord while looking at the blessings scattered on this planet all around. He will know that all these things have not been created uselessly; these are for the benefits of human being. And they should utilize it and should thank their Lord for these blessings. Now, human beings should struggle, work hard, and explore the hidden treasury that Allah saved them for their benefit. Allah says in the Holy Book Qur'an: "Only scholars in his creation be afraid of Allah" Khushal indicated the same point in the following couplet:

"No matter, how many hardships are there in seeking the knowledge, bear, Because ignorant cannot know the Allah

Education aims at a stable development of individuals through training of the spirit, the intellect, the rational self, feelings, and the senses. Good life is based on creative effort and struggle, which is the aim of education, as he said: Each minute which passes useless

Engage in such a job even if there is no remuneration for it"

The justification of not working by sick individuals is their illness

But why should healthy individuals not work (R. M Rasool, 2001). Syed. (1989), exhorted that Khushal Khan Khattak said about the hard work and predicted a wonderful invention which became true after four hundred years. "I asked, how I will fly to the sky...Replied, it is possible through the wings of struggle". He further stated: "Parents should have to struggle for the developing and training of their offspring from infancy till their adulthood, as education has no borders"

\section{Individuality is an Aim of Education}

Rasool, (1999), says that Khushal Khan Khattak mentioned the eagle in his poetry for its uniqueness, as this bird is brave, has a strong and alive ego, and keen-sighted. He was aware of its qualities because he had kept this bird on his hand. He desired these qualities for his ideal man.

"A man is he, who is kind and brave

Polite to people in actions and talk

His face his face, his word his word,

And his promise, (Biddulph, 1983)

Khushal describes the qualities of different people:

"Some individuals are born eagles and falcons

Some are small birds, they are different in degrees

Though the crane has lovely feathers and wings

But it cannot fly high like an eagle." (Mir, 1982) 
Education is a continuous training for a successful life. Therefore, taking an active part in attaining education is the demand for it. In Khushal's view, the real individual is that who embrace hardship and should fear from dangers. If one aims to change society, he needs to get an education and for this purpose, he must be ready for any challenging task. Afterword he will be able to bring change because education a factor of change it will change first individuals and then the system. Therefore, Khushal khan is very much against those individuals who are ease-loving, living luxury life, and fears from doing a challenging job. He wants to see courage, boldness, and struggle in his desired individual.

"Reaching to the destination is a must

No matter if the entire way becomes full of blood"

Syed Rasool, (2001), stated that Khushal Khan Khattak gives an example of those who bear hardships and afterword one can achieve his/her targets: "As the sugarcane bears the heat of fire, it becomes sugar candy...Then the fame of its taste spreads all around. Such training of the young ones is vital; their genuine qualities will be seen only as the sword shines with burnishing. "Nobody has seen the nest of the eagle/falcon, they have just heard about it."

\section{Deliverance of Education}

Khushal Khan had a clear vision about education. He was in this struggle to quench his thrust of knowledge by getting more and more education till his last breath. He was also in favor of female education, it shows us his educated progeny that one of his daughters was Taj Bibi, who studied many books and was a very learned lady. The $2^{\text {nd }}$ was Halimah, who was a scholar and a poetess also." Some of his sons were also very learned men. Like "Ashraf khan, Sadar Khan, Ghauhar Khan, Abdul Qader Khan, Sikandar Khan, and Afzal Khan, Abdul Qader Khan had also written a Deewan and Afzal khan, the grandson of Khushal Khan Khattak named Ashraf Khan, wrote the history of Pathans which became famous as TAREEKH-E- MURASSA" (Rasool, 1999). He was also of the views that human being must accept the natural changes and modified their life behavior with the changing season because it is nature which teach us many things.

\section{Discussion}

The above literature shows that Khushal Khan Khattak's style was extremely educational. $\mathrm{He}$ intended to educate, guide, and train the individuals with the divine teachings and through his vast experience and scholarship. He left no stone unturned to put even a layman on right track by exposing the salient features of different social, moral, and educational aspects. Khushal Khan Khattak was an educationist in the true sense because he knew the spirit of education. He struggled for the holistic development of individuals by writing various prose and poetry books. That is why he wished such education for his nation to produce individuals like eagles, not vultures. Khushal Khan not only educated his individuals through his prose and poetry rather he presented practical models for living a successful and purposeful life. First, he transferred his knowledge and skills to his daughters and sons and made them academically, morally, and sound. Thus, he delivered a practical message to his masses to be followed. Khushal khan wants that individual should have to be a guard for the people not to shed their blood like wolves which is also supported by (Khan, 2005). In nutshell, he was a preacher of love, peace, humanity, and sacrifice for others as such types of reforms can change the destiny of the nations. Khushal Khan's grave on which is written: "Da Afghan Pa nang mai watarala toora, nangyalai da zamanai Khushal Khattak Yam" (translation: "I have taken up the sword to defend the pride of the Afghan, I am Khushal Khattak, the honorable man of the age.")

\section{References}

Begum, F. \&. Khadija, M. (2007), Life and Works of the illustrious Khushal Khan

Biddulph, M. A (1951), The Poems of Khushal Khan Khattak, Manzoor printing press, Lahore, Pakistan.

Daud, D.K. (2007), Khushal and Folklore, Pashto Academy, Jadun printing press, Peshawar, Pakistan. Ghani K. (2002) Khushal Khan, (Rawalpindi, S.T Printer's Garamendi August 2002).

Ghani. K. (2002), Khushal Khan Khattak the Afghan warrior-poet and philosopher, S.T. Printers, Rawalpindi.

Kamel, D. M. (1951), Khusha's life and literature, Peshawar, Pashto Academy, Pashto Department, University of Peshawar.

Khalique H. (2016) Retrieved from the daily News Paper available at https://www.thenews.com.pk/ print/126079-Khushal-Baba. Khattak, (Peshawar, Pashto Academy, University of Peshawar. 
Maghmoom. Y. M (2005), Dastar Nama, Pashto Academy, department of Pashto, University of Peshawar

Mir. A.K. (1982), Khushal and Iqbal, Azeem Publishing house, Peshawar

Naseem, A. (2007), Dastar Nama, (Peshawar, Pashto Academy, University of Peshawar

Purdil. K. H (Year nil), Khushal's Deewan (Part-1) Jadun Press Peshawar

Qabil. K. D (2006), Amir Hamza Khan Shinwari, Life and Works, Pashto Academy, University of Peshawar

Rasool, S. M. R (1999), Book under the title: Armaghan-e-Khushal, Master printing press, Peshawar, Khyber Pakhtunkhwa.

Rasool, S. M. R (2001), Armaghan-e-Khushal, Master printing press, Peshawar, Pakistan. Ripon printing press, Lahore, Pakistan.

Shakeel, A. (2006), Swat Nama. (Peshawar, Pashto Academy, Jadun printing press, Peshawar.

Shinwari S. A. (2020) Mazloom Khushal book review article Published in Dawn, January 29th, 2020.

Syed, A. H (1989), Muntakhabbat-e- Khushal, (Peshawar, Pashto academy, university of Peshawar, Pakistan.

Syed. A. Q (1979), Education and National Reconstruction of Pakistan, first edition, 